\title{
A new, unusual rhynchonellide with a strophic shell from the Silurian of Iran
}

Leonid E. Popov, Vachik Hairapetian, Mansoureh Ghobadi Pour, and Tatiana L. Modzalevskaya Acta Palaeontologica Polonica 60 (3), 2015: 747-754 doi:http://dx.doi.org/10.4202/app.00030.2013

A new, unusual rhynchonellide brachiopod Jafarirhynchus alatus assigned to the newly established family Jafarirhynchidae is described from the Silurian (Telychian) of the Boghu Mountains in east-central Iran. It forms a low diversity association with the spiriferide Striispirifer ? ocissimus, which exhibits well preserved calcified brachial supports. A strophic shell, well-developed ventral interarea and liberosessile mode of life make this taxon unique among Palaeozoic rhynchonellide brachiopods. In spite of a superficial similarity to spiriferides and the atrypide family Davidsonioidea, Jafarirhynchus retains the typical rhynchotrematoid cardinalia with a septalium supported by the median septum, a septiform cardinal process and long, raduliform crura. It is considered as an offshoot of the local lineage, which includes two successive species of Stegocornu (family Rhynchotrematidae) which proliferated in Central Iran and adjacent Afghanistan during Aeronian time.

Key words: Rhynchonellida, morphology, taxonomy, Silurian, Telychian, Iran.

Leonid E. Popov [leonid.popov@museumwales.ac.uk], Department of Geology, National Museum of Wales, Cathays Park, Cardiff CF10 3NP, UK; Vachik Hairapetian [vachik@khuisf.ac.ir], Department of Geology, Khorasgan (Isfahan) Branch, Islamic Azad University, PO Box 81595-158, Isfahan, Iran; Mansoureh Ghobadi Pour [mghobadipour@yahoo.co.uk], Department of Geology, Faculty of Sciences, Golestan University, Gorgan 49138-15739, Iran; Tatiana L. Modzalevskaya [Tatiana Modzalevskaya@ vsegei.ru], Department of Stratigraphy and Palaeontology, Russian Geological Research Institute (VSEGEI), 74 Sredniy prospect, St. Petersburg 199106, Russia.

This is an open-access article distributed under the terms of the Creative Commons 
Attribution License (for details please see creativecommons.org), which permits unrestricted use, distribution, and reproduction in any medium, provided the original author and source are credited.

Fof Full text $(718.7 \mathrm{kB})$ 